\title{
An Appraisal of Housing and Neighbourhood Quality in Residential Estates in Akure, Nigeria
}

\author{
Abiodun Olukayode Olotuah \\ Department of Architecture, Federal University of Technology, Akure 340001, Nigeria \\ olotuah@gmail.com; aoolotuah@futa.edu.ng
}

\section{Doi:10.5901/mjss.2016.v7n3s1p424}

\section{Abstract}

This paper examines the quality of housing and the environment in two residential estates in Akure, the Ondo State capital, Nigeria. The two estates are situated at the fringe of the city; one was built by the state government and the other by the federal government. The paper reports findings from a research carried out on the housing estates. The presence and performance of public goods and services provided on community basis were examined and found to be deficient operationally. The material characteristics of the buildings and the physical environment in which they are situated were also examined. On both estates less than half of the buildings are sound and do not therefore require immediate repairs to bring them up to normative or structural quality. A few of the buildings are either dilapidated or require major repairs and are thus unfit for safe habitation. In spite of these however the residents generally are satisfied with the quality of their housing. The paper proffers recommendations on housing regeneration and the improvement of the quality of the neighbourhoods.

Keywords: building, environment, housing, regeneration, quality.

\section{Introduction}

Nigeria is a country experiencing rapid urbanisation. The urbanisation process predated its colonial experience, which is a principal factor responsible for the contemporary urban system in the country. The high rate of urbanisation is, however, not matched by a corresponding commensurate change in the rate of economic and technological development and social change (Mabogunje, 1980; Onibokun, 1985; Adedeji \& Olotuah 2012; Olotuah 2015;). It is taking place in the context of a stagnant economy and a relatively negligible growth of industrialization (Salau, 1992). The consequences of this are highly manifested in the crisis of housing provision for the poor majority living in the urban centres. The rate of supply of housing stock evidently lacks behind the quantitative need of the populace, and housing deficit has been observed as a visible enduring feature of the urbanisation process (Odongo, 1979). Studies have shown that the large proportion of the existing housing stock in Nigeria is largely inadequate qualitatively and is characterized by acute environmental and sanitary problems (Mabogunje, Hardoy, \& Misra, 1978; Filani, 1987; Ozo, 1987, Omojinmi, 2000; Olanrewaju, 2001; Olotuah, 1997, 2002; Daramola, Oluwole, Aduwo and Ogbiye, 2005).

In Nigeria where the public sector has initiated such programmes, they have been beset with a myriad of problems leading to colossal failure (Muoghalu, 1987; Atolagbe, 1997; Jiboye, 1997, Olotuah 2000, 2001). A number of reasons can be adduced for this, namely:

(i) The wrong perception of the housing needs of the poor majority by government,

(ii) The paucity of the houses provided by government which incidentally are too expensive for the poor and are thus acquired by higher income earners; and

(iii) Improper planning and poor execution of government's housing policies and programmes.

In its housing programmes the Nigerian public sector has been involved in direct housing construction as well as site-and-services schemes. The federal government in the Second Republic (1979-1983) proposed the construction of 2,000 dwelling units annually in each of the 19 states of the federation then, as well as the Federal Capital Territory. This was the first phase of its housing programme. By the end of its tenure that phase of the programmes achieved barely $15 \%$ of its set target (Federal Government of Nigeria FGN, 2004). The second phase did not even take off at all in most of the states of the federation. In Ondo state the federal government built 1280 units out of a target of 8,000. The buildings were built in estates tagged Federal Low-Cost Housing Estates. One of these is sited in Akure and is a subject of this paper.

The Ondo State Government established the State Housing Corporation in 1976 as the organ principally 
empowered to plan and execute its housing programmes. The main functions of the Corporation as provided by Edict No 3 of 1977, the instrument which established it, are to increase the availability, in the State, of dwelling houses, commercial and industrial buildings for acquisition by members of the public. The Corporation has established housing estates in a number of towns in the state, four of which are in Akure, the state capital. The Oba-lle Housing Estate is one of the estates and is also a subject of this paper.

\section{Housing Poverty in Nigeria}

Lewin (1981) argues that the rapid deterioration of urban housing is the visible and most obvious consequence of urbanisation and urban poverty. In spite of being a fundamental need for dignified living, a sine qua non for man's existence as affirmed by Yakubu (1980), housing is a major area of deprivation for the urban poor. Poor housing conditions manifest in the high proportions of people living in overcrowded accommodation devoid of the barest presence of public infrastructure and social amenities. This often is as a result of severe housing shortages in urban centres.

Housing shortages often lead to slum settlements which have been observed to pose problems of environmental health hazard (Abrams, 1966). This often generates deviant behaviours such as prostitution, criminality, and juvenile delinquency (Mangin, 1967; Huntington, 1968; Portes, 1971; Okoko 2001). Poor quality housing is thus not only hazardous to man's health and welfare it places definite limitation on the output and productivity of its occupants (Olotuah \& Aiyetan 2006). The high unequal income distribution in the country is further aggravated in such circumstances, which perpetuates the vicious circle of poverty, within the general populace. In contradistinction, housing intervention, stimulates the economy of a nation, and is thus a catalyst for rapid socio-economic development. It is a basis for guided urban development since housing is a part of the total demand package of man (Chattergee, 1982; Salau, 1992). The provision of other essential socio-economic services and public infrastructure is intricately intertwined with housing provision, which enhances the user population's general productivity and the acquisition of human capital, and thus their well being and quality of life.

In Nigeria, as in most Less Developed Countries (LDCs), access to quality housing is largely out of the economic reach of the majority of the populace. There is a high incidence of housing poverty, in quantitative and qualitative terms, in both rural and urban centres. The problems encountered in rural areas essentially emanate from poor quality of housing and the environment. The urban centres however suffer monumental deficiency in both the quantity of housing stock needed and the quality of available dwellings (Olotuah, 2005).

\section{Research Methodology}

This paper reports an aspect of a parent research carried out in two housing estates in Akure, the capital city of Ondo State, Nigeria. The objectives of the research include the examination of:

(i) The state of repair of the buildings on the estates,

(ii) The adequacy of the infrastructure and facilities on the estates; and

(iii) The spatial aggregation of the buildings on the estates.

This paper reports data on the Federal Low-Cost Housing Estate and the Oba-lle Housing Estate. The research instrument used for the study was a well-structured questionnaire designed to elicit data on pertinent issues on the research subject. The research adopted a data matrix of 44 variables by 120 cases. The variables were converted to questions, tacitly expressed in English Language. The cases studied were divided equally amongst the estates. Thus sixty copies of a questionnaire were administered randomly on each estate. The Oba-lle Housing Estate is at the suburb of the city, but still within Akure metropolis. On both estates there are buildings directly erected by government, and there are plots of land for sale on the sites-and-services programmes. For the latter a developer builds according to his desires but these must fall within planning regulations in operation on the estate as approved by the relevant agencies i.e. the State Housing Corporation and the Federal Ministry of Works and Housing, Akure.

This paper examines the quality of housing on both estates and the quality of the neighbourhoods themselves. It examines the physical attributes of the buildings, the environment in which they are situated and their arrangement into spatial units. These are factors that affect environmental quality (Mabogunje, 1980). Only a copy of the questionnaire was administered in a building with the household head as the respondent.

\section{Research Findings}

The findings of the research reported in this paper focus primarily on selected variables measuring. 
(i) The material characteristics of the buildings;

(ii) The amenities within dwellings units; and

(iii) The environment within which the buildings are situated.

Most of the buildings on both estates were built between 11 and 20 years of the period of the survey. About a tenth of the buildings were built within the last decade. The materials used for wall construction were mainly sandcrete (cement) blocks, sundried or burnt bricks and timber. On the Federal Low-Cost Housing Estate $63 \%$ of the buildings have sandcrete blockwalls and in 33\% timber was used either wholly or partly as walling material. On Oba-lle Housing Estate, $68 \%$ of the buildings were built of sandcrete blocks and sundried or burnt bricks were used in $25 \%$ of the buildings (Table 1).

Table 1: Materials used for walls

\begin{tabular}{|l|l|c|}
\hline Location & Materials & $\%$ \\
\hline Federal Low Cost Housing Estate & Timber & 33.3 \\
& Sundried/burnt bricks & 03.4 \\
& Sandcrete blocks & 63.3 \\
\cline { 2 - 3 } & Total & 100 \\
\hline Oba-lle Housing Estate & Mud & 05.0 \\
& Timber & 01.7 \\
& Sundried/burnt bricks & 25.0 \\
& Sandcrete blocks & 68.3 \\
\hline & Total & 100 \\
\hline
\end{tabular}

Source: Fieldwork 2015

The analysis of the state of repair of the buildings indicates that $35 \%$ and $45 \%$ of them in Oba-lle Housing Estate and Federal Low-Cost Housing Estate respectively are sound and thus do not require immediate repairs to make them habitable. In the latter $15 \%$ of the buildings are either dilapidated or require major repairs. These buildings have normative and structural deficiencies and are unsafe for habitation. The other buildings on the estate, which constitute $40 \%$, require minor repairs to bring them to satisfactory conditions. On Oba-lle estate the proportion of buildings that require minor repairs is $56.7 \%$, while those that require major repairs and are unfit for dignified living are $8.3 \%$ (Table 2).

Table 2: State of repair of buildings

\begin{tabular}{|l|l|c|}
\hline Location & State & $\%$ \\
\hline Federal Low Cost Housing Estate & Dilapidated & 06.7 \\
& Requires major repairs & 08.3 \\
& Requires minor repairs & 40.0 \\
& Sound & 45.0 \\
\cline { 2 - 3 } & Total & 100 \\
\hline Oba-Ile Housing Estate & Dilapidated & 0.0 \\
& Requires major repairs & 08.3 \\
& Requires minor repairs & 56.7 \\
& Sound & 35.0 \\
\hline & Total & 100 \\
\hline
\end{tabular}

Source: Fieldwork 2015

Hand-dug wells are the major source of water supply on both estates. On the federal estate they constitute $63 \%$ while on Oba-lle Housing Estate they supply water to $82 \%$ of the residents. On Oba-lle Estate only $5 \%$ of the residents have water from the public mains. Public taps are however on the federal estate from which $27 \%$ of the residents derive water for use (Table 3). 
Table 3: Sources of water supply

\begin{tabular}{|l|l|c|}
\hline Location & Source & $\%$ \\
\hline Federal Low Cost Housing Estate & None & 08.3 \\
& Well & 63.3 \\
& Borehole & 01.7 \\
& Public tap outside & 26.7 \\
\cline { 2 - 3 } & Total & 100 \\
\hline Oba-lle Housing Estate & None & 01.7 \\
& Well & 81.7 \\
& Borehole & 11.6 \\
& Public tap outside & 05.0 \\
\hline & Total & 100 \\
\hline
\end{tabular}

Source: Fieldwork 2015

Electricity supply is mainly erratic on both estates. This is asserted by half of the residents. Only about on $30 \%$ of the residents have electricity supply between 6 to 12 hours daily. On Oba-lle housing estate electricity is available to 13\% between 12 to 24 hours daily while it occurs for only $5 \%$ of the residents on the federate estate (Table 4).

Table 4: Electricity supply from public mains

\begin{tabular}{|l|l|c|}
\hline Location & Hours & $\%$ \\
\hline Federal Low Cost Housing Estate & Erratic & 51.6 \\
& Less than 6hours daily & 15.0 \\
& $6-12$ hours daily & 28.4 \\
& Above 12hours & 05.0 \\
\cline { 2 - 3 } & Total & 100 \\
\hline Oba-Ile Housing Estate & Erratic & 53.4 \\
& Less than 6hours daily & 06.7 \\
& $6-12$ hours daily & 26.7 \\
& Above 12hours & 13.2 \\
\hline & Total & 100 \\
\hline
\end{tabular}

Source: Fieldwork 2015

Water closets (WCs) are available in every building on the Oba-lle estate. However this facility is shared in one-sixth of the cases. On the federal estate water closets are available in two-thirds of the buildings while pit latrines feature in a quarter. In the remaining one-twelfth, no toilet facilities whatsoever are available. Toilet facilities are used exclusively in less than $50 \%$ of the cases on the federal estate.

On both estates kitchens are provided as distinct rooms designated for the specific purpose within the dwelling units. This is the situation in $88 \%$ of the cases studied on Oba-lle housing estate. On the federal estate such rooms are only available in $57 \%$ of the buildings. Cooking is done along the corridor in $38 \%$ of the buildings (Table 5).

Table 5: Distribution of households by kitchen type

\begin{tabular}{|l|l|c|}
\hline Location & Type & $\%$ \\
\hline Federal Low Cost Housing Estate & None & 03.4 \\
& Along the corridor & 38.3 \\
& Detached room outside & 01.7 \\
& Room within the house & 56.6 \\
\cline { 2 - 3 } & Total & 100 \\
\hline Oba-Ile Housing Estate & None & 03.4 \\
& Along the corridor & 05.0 \\
& Detached room outside & 03.3 \\
& Room within the house & 88.3 \\
\hline & Total & 100 \\
\hline
\end{tabular}

Source: Fieldwork 2015 
Refuse burning is the predominant means of waste disposal on both estates, especially Oba- Ile Housing Estate where $78 \%$ of the population engage in it. On the federal estate $37 \%$ of the residents burn their refuse while $35 \%$ dispose theirs in refuse dumps. Refuse dumps are rather uncommon on Oba-lle Estate. The State Waste Management Board caters for the disposal of wastes for a tenth of the population on the federal estate. Their impact is not felt on Oba-lle estate where $1.7 \%$ enjoys their services (Table 6 ).

Table 6: Mode of refuse/waste disposal

\begin{tabular}{|l|l|c|}
\hline Location & Type & $\%$ \\
\hline Federal Low Cost Housing Estate & Refuse dumping & 35.0 \\
& Burning & 36.7 \\
& Contractor/company & 06.7 \\
& Waste management board & 10.0 \\
& Others & 11.6 \\
\cline { 2 - 3 } & Total & 100 \\
\hline Oba-Ile Housing Estate & Refuse dumping & 18.3 \\
& Burning & 78.3 \\
& Contractor/company & 00.0 \\
& Waste management board & 01.7 \\
& Others & 01.7 \\
\hline & Total & 100 \\
\hline
\end{tabular}

Source: Fieldwork 2015

The frequency of waste disposal is higher on the federal estate. About $38 \%$ disposes their wastes a few times a week while $20 \%$ does so on daily basis. One-sixth of the population disposes theirs weekly. On the Oba-lle Housing Estate half of the population does so weekly whereas $35 \%$ claim they are uncertain of the frequency of the disposal of their wastes.

Wastewater discharged from kitchens and bathrooms is efficiently evacuated on Oba-lle Housing Estate. On 87\% of the cases wastewater is either discharged into soak away pits or into drains outside. However in $13 \%$ of the buildings wastewater is spilled all over the house grounds creating puddles of water and this increases the degradation of the environment. On the federal estate wastewater is discharged into soak away pits and drains outside in $62 \%$ of the cases. Thus, in the remaining $38 \%$ wastewater evacuation is not adequately accounted for which also considerably vitiates the quality of the environment (Table 7).

Table 7: Mode of evacuation of wastewater

\begin{tabular}{|l|l|c|}
\hline Location & Type & $\%$ \\
\hline Federal Low Cost Housing Estate & No drains & 38.4 \\
& Drains & 35.0 \\
& Soak away pits & 26.6 \\
\cline { 2 - 3 } & Total & 100 \\
\hline Oba-lle Housing Estate & No drains & 13.4 \\
& Drains & 31.6 \\
& Soak away pits & 55.0 \\
\hline & Total & 100 \\
\hline
\end{tabular}

Source: Fieldwork 2015

The location of the kitchens in the buildings enables thorough evacuation of smoke. Smoke diffuses into the backyard in most of the cases. However in a quarter of them on the federal estate smoke either diffuses into the ceiling less roofs of the buildings or streams into the buildings. This happens only in $18 \%$ on Oba-lle housing estate.

The spatial aggregation of the buildings on both estates is indicative of adherence to planning regulations. The buildings are spaciously located in relation to one another, which eliminates the inherent problems in overcrowding of buildings in terms of amounts of air, light, odour and noise in the buildings.

The residents of both estates are, to a large extent, satisfied with the quality of their housing as well as their neighbourhoods. Close on $75 \%$ of the residents of both estates considers their housing as either very satisfactory or 
satisfactory. This is also the perception of the residents of Oba-lle Housing Estate on the quality of their neighbourhood. On the federal estate, however, less than $50 \%$ considers their neighbourhood as very satisfactory or satisfactory. Almost $30 \%$ of them even perceives the quality as poor.

The chi-square tests performed on the research data show that housing quality has significant relationship with State of repair, Mode of refuse disposal, Frequency of refuse disposal, Source of water supply, and Type of toilet. The chi square results are shown on Table 8.

Table 8: Chi square results

\begin{tabular}{|c|c|c|}
\hline Variables: Housing Quality & Chi square value & Significance \\
\hline State of repair & 51.262 & $.000^{* *}$ \\
\hline Mode of refuse disposal & 20.280 & $.000^{* *}$ \\
\hline Frequency of refuse disposal & 32.058 & $.000^{* *}$ \\
\hline Source of water supply & 4.391 & $.036^{\star}$ \\
\hline Type of toilet & 39.47 & $.000^{* *}$ \\
\hline
\end{tabular}

The relationship between housing quality and the variables is significant at either $100 \%$ confidence level or $95 \%$ confidence level ( $\alpha=0.05,5 \%$ significance level), which is the critical point adopted in the research.

\section{Policy Implications and Recommendations}

Housing regeneration is required on both estates. The state of repair of the buildings there is indicative of their habitability. Most of the buildings require one form of repairs or the other. Some of them are dilapidated and are unfit for habitation. In such cases there are walls, which have fallen off, and roofs that are either leaking or have caved in. Sanitary facilities, doors and shutters have been vandalized in a good number of them. These buildings require complete redevelopment.

Management agencies need to be set up on both estates to cater for problems that generally beset the resident population, and ensure that the buildings meet basic requirements for habitability. Public goods and services supplied on community basis, which are not functioning properly, should be looked into by the agencies. Public water supply is hardly available on the estates and where available it is unreliable. The alternative sources on both estates, which are predominant, are hand-dug wells. The wells, however, often dry up in the dry season. Bore holes, which are deeper than wells, and provide safer drinking water, are better alternatives, which should be provided by the management agencies. This will enhance the quality of housing on the estates and consequently their livability.

Electricity supply is erratic on both estates. The problem of electricity supply is a national one since this is more of power generation and distribution by the National Electric Power Authority. However local problems often compound the situation which management agencies are suitably placed to tackle. These include bad 'transformers, feeder pillars and transmission wires.

Refuse disposal is of paramount importance in maintaining the quality of the environment. The incidence of refuse burning is recorded on both estates and it is the most visible means of waste disposal. This is done on individual plots and in such an indiscriminate manner that air pollution is prevalent. It is imperative that incinerators should be provided on the estates and a collection procedure is put in place to get the wastes there. This will eliminate the creation of unsightly refuse dumps and indiscriminate refuse burning. The State Waste Management Board should be encouraged to extend their services to the estates to further improve the level of cleanliness of the estates. The evacuation of slop water from rain run-off and wastewater discharged from kitchens and bathrooms should be enhanced by the provision of drains within the individual plots, as well as along the roads on the estates.

\section{Conclusion}

This paper discusses the quality of housing on two residential estates in Akure, Nigeria. It examines the quality of their environment vis-a-vis the satisfaction of the residents with them. It establishes the inadequacy of the provision and performance of basic services and the poor state of repair of a good number of buildings on the estates. These inadequacies have to be addressed to enhance the quality of housing and their environmental quality. 


\section{References}

Abrams, C. (1966) Squatter Settlements: The Problem and Opportunity, Division of International Affairs, Department of Housing and Urban Development, Washington D.C.

Adedeji Y. M. D. and Olotuah A. O. (2012) "Accessibility of Low-Income Earners to Housing Finance in Nigeria" European Scientific Journal, June edition, 8 (12) ISSN: 1857 - 7881 (Print) e - ISSN 1857- 7431, 80 - 95

Atolagbe, A.M.O. (1997): "Affordable Shelter for the Urban Low-Income Classes in Nigeria: Local Resources Strategies" In The House In Nigeria, Conference Proceedings, Obafemi Awolowo University (O.A.U) lle-Ife, July 23-24, 274 - 279

Chattergee, L. (1982) "Effective Targeting for Basic Shelter Provision" Economic Geography, 58, (1) 63 - 74

Daramola A., A. Oluwole, B. Aduwo and S. Ogbiye (2005): "Public-Private Partnership and Housing delivery in Nigeria, Conference Proceedings of Africa Union of Architects Congress, Abuja, 23-28 May, 26 - 44

Federal Government of Nigeria, FGN (2004): The National Housing Policy, Federal Ministry of Works and Housing, Lagos.

Filani, M.O. (1987) "Accessibility and Urban Poverty in Nigeria" In The Urban Poor in Nigeria, Makinwa P.K. and Ozo O.A. (Eds.) Evans Brothers Nig. Publishers Ltd., Ibadan, 128 - 138

Huntington, S.P. (1968) Political Order in Changing Societies, Yale University Press, New Haven

Jiboye, A. (1997): "A Critique of Official Housing Policies in Nigeria" In Bayo Amole (Ed.) The House in Nigeria, Proceedings of the National Symposium, Obafemi Awolowo University lle-Ife, Nigeria, 23 - 24 July, 284-288

Lewin, A.C. (1981) Housing Co-operatives in Developing Countries, John Wiley and Sons, New York, 1981

Mabogunje, A.L. (1980) The Development Process: A Spatial Perspective 2nd Ed., Unwin Hyman Ltd, London

Mabogunje, A.L., Hardoy, J.E. and Misra, P.R. (1978) Shelter Provision in Developing Countries. The Gresham Press, Survey

Mangin, W. (1967) "Latin American Squatters Settlements: A problem and a solution" Latin American Research Review, 2, 65 - 98

Muoghalu, L.N. (1987): "The Urban Poor and Accessibility to Public Housing in Nigeria" In The Urban Poor in Nigeria. Makinwa P.K. and O.A. Ozo (Eds.), Evans Brothers Publishers Nig Ltd. Ibadan, 161 - 171

Odongo, J. (1979) "Housing Deficit in Cities of the Third World: Fact or Fiction?" In Housing in Third World Countries Perspectives on Policy and Practice, Murrison H. S. and Lea J.P. (Eds.), The Macmillan Press Ltd., London, 31 - 35

Okoko, E. (2001): "Residential Crowding and Privacy in High-Density Neighbourhoods in Akure, Nigeria" In Ife Social Sciences Review, 19 (1) $133-144$

Olanrewaju, D.O. (2001). Urban Infrastructure A critique of Urban Renewal Process in ljora, Badia. Habitat International, 20: 517-530.

Olotuah A. O. (1997): "The House: Accessibility and Development - A Critical Evaluation of the Nigerian Situation" In Bayo Amole (Ed.) The House in Nigeria, Proceedings of the National Symposium, Obafemi Awolowo University lle-lfe, Nigeria, 23 - 24 July, 312 317

Olotuah, A.O. (2001): "Housing Delivery and Financial Intermediation: An Appraisal of the Roles and Performances of Mortgage Institutions in Nigeria" The Quantity Surveyor, 35, 20-27

Olotuah A. O. (2002) "An Appraisal of the Impact of Urban Services on Housing in Akure Metropolis" Journal of Science, Engineering and Technology, 9 (4) 4570-4582

Olotuah, A. O. (2005): "Sustainable Urban Housing Provision in Nigeria: A Critical Assessment of Development Options" Proceedings of the Africa Union of Architects Congress, Abuja, 23 - 28 May, 64 - 74

Olotuah A.O. (2015): "Assessment of Qualitative Adequacy of Public Housing Schemes in Ado-Ekiti, Nigeria" Journal of Civil and Environmental Research, 7 (8) 58 - 62, http://www.iiste.org/Journals/index.php/CER/article/view/24640

Olotuah, A. O. and Aiyetan A. O. (2006): "Sustainable Low-Cost Housing Provision in Nigeria: a bottom-up, participatory approach" In Boyd, D (Ed.) Proceedings of 22nd Annual ARCOM Conference, 4 - 6 September, Birmingham, UK, Association of Researchers in Construction Management, 2, $633-639$

Omojinmi, I.O. (2000): SINA Technical Workshop on Housing Co-operatives, Nairobi 6 - 17 October

Onibokun, A.G. (1985) "Housing Finance in Nigeria: A Critical Survey of Private and Public Sources." In Housing in Nigeria, Onibokun A.G. (Ed) Nigerian Institute of Social and Economic Research (N.I.S.E.R) Ibadan, $199-219$

Ozo, A.O. (1987) "Housing Conditions of the Urban Poor in Benin City"In The Urban Poor in Nigeria. Makinwa P.K. and O.A. Ozo (Eds.), Evans Brothers (Nigeria) Publishers Ltd. Ibadan, 227 - 244

Portes, A. (1971) "The Urban Slums in Chile: Types and Correlates." Land Economics, 47, 235 - 248

Salau, A.T. (1992) "Urbanisation, Housing and Services in Nigeria: The Challenge of Meeting. Basic Needs" In Cities and Development in the Third World, $51-69$

Yakubu, M. (1980) "Low-Cost Housing and Housing for Low-Income Groups." In The Proceedings of the $3^{\text {rd }}$ International Conference on Housing, August 17-24, Durbar Hotel Kaduna, Nigeria, 218 - 223 